\title{
The Competitiveness of New Development of Ten Tourist Destination in Indonesia.
}

\author{
Candra Hidayat \\ ${ }^{1}$ Sekolah Tinggi Pariwisata Trisakti, Jakarta, Indonesia \\ Email: candra.hidayat@stptrisakti.ac.id
}

\begin{abstract}
This research investigates the competitiveness of new development ten tourist destinations performance in Indonesia. It deeply analyzes fourteen pillars organized into four broad factors of competitiveness. First board is the enabling environment has five pillars: 1.Business environment, 2.Safety and security, 3.Health and hygiene, 4.Human resources and labour market and 5.ICT readiness. Second board is travel and tourism policy and enabling conditions has four pillars:1.Prioritization of travel \& tourism, 2.International openness, 3.Price competitiveness and environmental sustainability. Third board is the infrastructure has three pillars:1.Air transport infrastructure, 2.Ground and port infrastructure and 3.Tourist service infrastructure. Fourth board is the natural and cultural resources has two pillars: 1.Natural resources and2.Cultural resources and business travel. Type of study is descriptive and the research focuses use secondary data. According to the result, the rank of new development tourist destinations will be number ten is North Maluku with score 3.032, number nine is East Nusa Tenggara with score 3.783, number eight is Southeast Sulawesi with score 3.946, number seven is Bangka Belitung with score 4.155, number six is West Nusa Tenggara with score 5.113, number five is North Sumatra with score 5.500, number four is Central Java with score 5.794, number three is Jakarta with score 5.931, number two is Banten with score 5.978 and number one is East Java with score 6.906.
\end{abstract}

Keywords: Economic, Travel \& Tourism, Tourism Destination, Travel \& Tourism Competitive Index, Indonesia Tourism

\section{INTRODUCTION}

According to Ocean Health Index said the travel and tourism industry is an important part of the overall global economy, and is particularly important in some developing nations, where it can help to reduce poverty. (Ocean Health Index, 2017)

Moreover based on research information from Travel \& Tourism is a key sector for economic development and job creation throughout the world. In 2016, Travel \& Tourism directly contributed US\$2.3 trillion and 109 million jobs worldwide. Taking its wider indirect and induced impacts into account, the sector contributed US\$7.6 trillion to the global economy and supported 292 million jobs in 2016. This was equal to $10.2 \%$ of the world's GDP, and approximately 1 in 10 of all jobs. (WTTC, 2017)

Lonely planet defined Indonesia's numbers astound: more than 17,000 islands, of which 8000 are inhabited, and over 300 languages spoken across them. It's a beguiling country offering myriad adventures. The world's fourth most populous country is a sultry kaleidoscope draped along the equator for $5000 \mathrm{~km}$. From Sumatra's western tip to Papua's eastern edge, Indonesia defies homogenization. It's a land of so many cultures, peoples, animals, customs, plants, sights, artworks and foods that it's like 100 countries melded into one. The people are as radically different from each other as if they came from different continents, with every island a unique blend of the people who live there. Over time, deep and rich cultures have evolved, from the mysteries of the spiritual Balinese to the utterly non-Western belief system of the Asmat people of Papua. (Lonely planet, 2017).

The government has announced ten new destination brands to support the Wonderful Indonesia campaign in an attempt to attract 15 million foreign tourists in 2017 and 20 million in 2018. The ten tourist destinations are Lake Toba in North Sumatra, Tanjung Kelayang in Bangka Belitung, Tanjung Lesung in Banten, Thousand Islands regency in Jakarta, Borobudur in Central Java, the areas of Bromo, 
Tengger and Semeru in East Java, Mandalika in West Nusa Tenggara, Labuan Bajo in East Nusa Tenggara, Wakatobi in Southeast Sulawesi and Morotai in North Maluku.(The Jakarta post, 2017).

\section{A. Travel \&Tourism.}

\section{LITERATURE REVIEW}

Travel \& Tourism is an important driver of economic, social, and cultural development in both developed and developing countries. Unlike traditional industries (e.g. manufacturing, communications, financial services, etc.), Travel \& Tourism can be a significant economic driver in remote areas of countries far from economic centers, as well as in the major business and administrative centers. And The World Travel \& Tourism Council (WTTC) divided on three levels. Firstly Direct, this includes only those employees and the related value added for the relevant sector. In the case of Travel \& Tourism, we only count the value added of the accommodation, recreation, transportation, and other related sectors. Secondly Indirect, this measures the supply chain impact (also called inter-industry linkages) for each sector (Printing/publishing, utilities, financial services, sanitation services, furnishing \& equipment suppliers, security services, rental car manufacturing, transportation, administration, ship building, tourism promotion, aircraft manufacturing, resort development, glass products, iron/steel). Thirdly Induced, this measures the impacts of incomes earned directly and indirectly as they are spent in the local economy. The sum of direct, indirect, and induced impacts equals the total economic impact of a sector. (WTTC, 2012)

\section{B. Travel \& Tourism Competitiveness Index}

The Travel \& Tourism Competitiveness Index (TTCI) measures "the set of factors and policies that enable the sustainable development of the Travel \& Tourism sector, which, in turn, contributes to the development and competitiveness of a country". The T\&T Competitiveness Index measures four broad factors of competitiveness. These factors are organized into sub indexes, which are further divided into 14 pillars: A).The Enabling Environment sub index, which captures the general settings necessary for operating in a country: 1.Business Environment, 2.Safety and Security,3.Health and Hygiene, 4.Human Resources and Labour Market, 5.ICT Readiness. B).The T\&T Policy and Enabling Conditions sub index, which captures specific policies or strategic aspects that impact the T\&T industry more directly: 6.Prioritization of Travel and Tourism, 7.International Openness, 8.Price Competitiveness, 9.Environmental Sustainability. C).The Infrastructure sub index, which captures the availability and quality of physical infrastructure of each economy: 10.Air Transport Infrastructure, 11.Ground and Port Infrastructure, 12.Tourist Service Infrastructure. D). The Natural and Cultural Resources sub index, which captures the principal "reasons to travel": 13. Natural Resources, 14.Cultural Resources and Business Travel. (WEF,2017)

\section{Foreign direct investment}

Foreign Direct Investment is defined as "an investment involving a long-term relationship and reflecting a lasting interest of a resident entity (individual or business) in one economy (direct investor) in an entity resident in an economy other than that of the investor (host Country).There are several classification effects of foreign direct investment listed of the seven major effects: 1.Income effects through the contribution of foreign direct investment in total capital formation in the host country. This effect is positive to the extent that the newly generated investment raises gross domestic product and national incomes. 2.Employment effects, i.e. job opportunities created by FDI which did not exist before. 3.Balance of payment affects embracing not only the balance between increased exports and the rise in imports required to support new production but also the inflow of fresh capital against remittances and retrievals. 4.Structural effects such as the emergence of new lines of production for facilitating or further processing, i.e. backward and forward linkages. A generalized structural effect refers to the sectorial composition of the economy as a whole. 5.Technology transfer through the application of more sophisticated knowhow in production. The transfer may be affected through the technology embodied in 
foreign direct investment and also through the upgrading of skills associated with foreign direct investment activities. 6.Market effects which may be either positive when foreign direct investment sets a good example for domestic entrepreneurs to follow or negative when domestic businessmen are crowded out by foreign ones. 7.Taxation effects appearing as a logical corollary to rising corporate and personal incomes. Benefits accruing to host country governments on this account are often significantly reduced by tax holidays and other incentives to attract foreign direct investment, at least during the initial stage of building up foreign direct investment. (Linblad, 1998).

\section{Tax}

Local government revenues (PAD) are revenues sourced and levied by the local government. PAD sources consist of: local taxes, regional restitution, profits from regionally-owned enterprises (BUMD), and other legitimate local revenue. Warsito (2001: 128)

\section{E. Health and Hygiene}

The definition of sanitation improvement facility is a hygiene of separation human excreta from human, animal and insect contact. Therefore, the improvement of sanitation facilities consists of flush/pour-flush toilets that connected to a sewer, septic tank or pit, improvement of ventilation of pit latrines, pit latrines is a platform of any material which covers the pit entirely, except for the drop hole; and composting toilets/latrines. However, unimproved facilities consist of shared facilities which flush/pour-flush toilets that discharge directly into an open sewer or ditch or elsewhere pit latrines without a slab; bucket latrines; hanging toilets or latrines; and the practice of open defecation in the bush, field or directly on the river. (mdgs.un.org, 2017)

On the other hand, a drinking water source is also protected from outside contamination with fecal matter to improve its hygiene. The improvement of drinking water sources includes dwelling, plot or yard of piped water, tap/standpipe; borehole/tube well; protected dug well; protected spring; rainwater collection and bottled water. Moreover, the consideration of bottled water users is to have access to improved sources only when they have a secondary source to an otherwise improved type. Nevertheless, the improvement of drinking water sources do not include unprotected wells, unprotected springs, water provided by carts with small tanks/drums, tanker truck-provided water and bottled water or surface water taken directly from rivers, ponds, streams, lakes, dams, or irrigation channels. The reason is because drinking water is set as water used for ingestion, food preparation and basic hygiene purposes. (mdgs.un.org, 2017)

\section{F. ICT readiness}

Telecommunication means transmission, delivery and admission of information by signs, signals writing, images, voices and sounds are through a wire, optical, radio, or other electromagnetic systems. The provision of voice transmitters, data, text, sound and video using transmission facilities is telecommunication activities that based on a single technology or a combination of any kinds of technologies. (BPS, 2015).

Telecommunications subscribers are also used by individuals, legal entities, and government to utilize telecommunications networks or services either by contract or without contract. (BPS, 2015).

A network component of cellular communication systems receive and send signals that called as Base Transceiver Station (BTS). It serves the users' communication device with the network to other networks. (BPS, 2015).

\section{G. Brand strategy rating}

A Country, Region, or City Brand is a utility that managed by several of methodologies in order to attain its desired objectives. Bloom Consulting establishes five different Country, Region, and City (CRC) Branding objectives, which are Attraction of Investment, Attraction of Tourism, Attraction of Talent, Strengthening Prominence and Strengthening Exports. (Bloom Consulting, 2017). 


\section{H. Regional government budget}

According to the Regulation of the Minister of finance Indonesia number 332004 is regional government budget (APBD), is an annual financial plan of local government in Indonesia approved by the regional representative council. APBD is determined by Regional Regulation.

\section{Infrastructure}

Based on American Public Works Association (Stone, 1974 in Kodoatie, R., 2005), infrastructure is physical facilities developed for functions governance in the provision of water, electricity, waste disposal, transportation and similar services to facilitate social and economic goal.

\section{J. Natural resources}

As permanent forest, forest area is a specific area of forest ecosystem determined by the government. Their decision is significant to arrange maintain the size of forest area and to ensure its legitimation and border demarcation of permanent forest.

The Minister of Forestry in the format of Ministerial Decree on the Designation of Provincial Forest Area and Inland Water, Coastal, and Marine Ecosystem establishes Indonesian forest area. The formula of the designation of Forest Area is based on integration and harmonization in Provincial Spatial Planning and Forest Land Use by Consensus.

The design of forest area covers inland water, coastal and marine ecosystem that may become part of Sanctuary Reserve Area and Nature Conservation Area. Sanctuary Reserve Area is a specific aquatic area for ecosystem of biodiversity plant and animal and its life support system. Moreover, a Nature Conservation area is a specific aquatic area that is to serve life support system of plant and animal species, as well as sustainable living resources and their ecosystems.

According to the Act on Forestry No. 41/1999, forest area is classified by Conservation Forest, Protection Forest and Production Forest. First, Conservation Forest is a forest area that has specific characteristic in the purposes of conservation of animal and plant species as well as their ecosystem. It is divided into Sanctuary Reserve area consists of Strict Nature Reserve and Wildlife Sanctuary, and Nature conservation area consists of National Park, Grand Forest Park, and Nature Recreation Park. Second, Protection Forest is a forest area that serves life support system, arrange hydrological system, prevent of flood, erosion control, seawater intrusion, and maintain soil fertility. Third, Production Forest is a forest area that promotes sustainable forest production; it is categorized into permanent production forest, limited production forest, and convertible production forest.(BPS, 2017).

\section{A. Research method}

\section{METHODS}

This research is aimed to study about the competitiveness of new development ten tourist destinations' performance in Indonesia. The object of the research will focus on the new development ten tourist destinations in Indonesia. In order to get a balance and reliable understanding and representations of the current situation toward son the new development ten tourist destinations in Indonesia. The number of tourist destination is 10 destinations. This number is becoming the population of the study. Type of study is descriptive and the research focuses use secondary data

\section{B. Conceptual framework}

This study intends to explore about the competitiveness of new development ten tourist destinations' performance in Indonesia. 


\section{Travel \& Tourism Competitiveness Index}

\begin{tabular}{|c|c|}
\hline $\begin{array}{l}\text { North Sumatra } \\
\text { Bangka Belitung } \\
\text { Banten }\end{array}$ & $\begin{array}{l}\text { Enabling Environment } \\
\text { 1.Business Environment } \\
\text { 2.Safety and Security } \\
\text { 3.Health and Hygiene } \\
\text { 4.Human Resource\& Labour Market } \\
\text { 5.ICT Readiness }\end{array}$ \\
\hline $\begin{array}{l}\text { Jakarta } \\
\text { Central Java } \\
\text { East Java }\end{array}$ & $\begin{array}{l}\text { T\&T Policy \&Enabling Conditions } \\
\text { 1.Prioritization of Trave1 \& Tourism } \\
\text { 2.International Openness } \\
\text { 3.Price competitiveness } \\
\text { 4.Environmental Sustainability }\end{array}$ \\
\hline $\begin{array}{l}\text { West Nusa Tenggara } \\
\text { East Nusa Tenggara }\end{array}$ & $\begin{array}{l}\text { Infrastructure : } \\
\text { 1.Air Transport Infrastructure } \\
\text { 2. Ground and port infrastructure } \\
\text { 3. Tourist Service Infrastructure }\end{array}$ \\
\hline North Maluku & $\begin{array}{l}\text { Natural and Cultural Resources : } \\
\text { 1.Natural Resources } \\
\text { 2.Cultural Resources \& Business Trave1 }\end{array}$ \\
\hline
\end{tabular}

FIGURE I. CONCEPTUAL FRAMEWORK

According to the program new development ten tourist destinations from the Minister of Tourism Republic Indonesia and Travel and tourism competitiveness index from World Economic Forum. Variable and Indicator showed in Table I.

TABLE I, CONCEPTUAL FRAMEWORK

\begin{tabular}{|c|c|}
\hline Variable & Indicator \\
\hline \multicolumn{2}{|l|}{ Enabling Environment } \\
\hline 1. Business Environment & 1.1 Impact of rules on FDI \\
\hline & 1.2 Time required to deal with construction permits \\
\hline & 1.3 Time to start a business \\
\hline & 1.4 Cost to start a business \\
\hline & 1.5 Total tax rate \\
\hline 2. Safety and Security & 2.1 Business costs of crime and violence \\
\hline & 2.2 Reliability of police services \\
\hline & 2.3 Homicide rate \\
\hline 3. Health and Hygiene & 3.1 Physician density \\
\hline & 3.2 Access to improved sanitation \\
\hline & 3.3 Access to improved drinking water \\
\hline & 3.4 Hospital beds \\
\hline & 3.5 HIV prevalence \\
\hline & 3.6 Malaria incidence \\
\hline 4. Human Resource \& Labour Market & Qualification of the labour force : \\
\hline & 4.1 Primary education enrolment rate \\
\hline & $\begin{array}{l}\text { 4.2 Secondary education enrolment rate } \\
\text { Labour market: }\end{array}$ \\
\hline & 4.3 Ease of finding skilled employees \\
\hline & 4.4 Pay and productivity \\
\hline & 4.5 Female labour force participation \\
\hline
\end{tabular}




\begin{tabular}{|c|c|}
\hline Variable & Indicator \\
\hline \multicolumn{2}{|l|}{ Enabling Environment } \\
\hline \multirow[t]{5}{*}{ 5. $\quad$ ICT Readiness } & 5.1 Internet use for business-to-consumer transactions \\
\hline & 5.2 Individuals using the internet \\
\hline & 5.3 Mobile telephone subscriptions \\
\hline & 5.4 Mobile network coverage \\
\hline & 5.5Quality of electricity supply \\
\hline T\&T Policy and Enabling Condition & \\
\hline \multirow[t]{4}{*}{ 6. Prioritization of Travel \& Tourism } & 6.1 Government prioritization of travel and tourism industry \\
\hline & 6.2 T\&T government expenditure \\
\hline & 6.3 Effectiveness of marketing to attract tourists \\
\hline & 6.4 Country Brand Strategy rating \\
\hline 7. International Openness & 7.1 Visa requirements \\
\hline \multirow[t]{3}{*}{ 8. Price Competitiveness } & 8.1 Ticket taxes and airport charges \\
\hline & 8.2 Purchasing power parity \\
\hline & 8.3 Fuel price levels \\
\hline \multirow[t]{6}{*}{ 9. Environmental Sustainability } & 9.1 Sustainability of travel \& tourism industry development \\
\hline & 9.2 Particulate matter (2.5) concentration \\
\hline & 9.3 Baseline water stress \\
\hline & 9.4 Forest cover change \\
\hline & 9.5 Wastewater treatment \\
\hline & 9.6 Coastal shelf fishing pressure \\
\hline Infrastructure & \\
\hline \multirow[t]{4}{*}{ 10. Air Transport Infrastructure } & 10.1Available seat kilometers, domestic \\
\hline & 10.2Available seat kilometers, international \\
\hline & 10.3Aircraft departures \\
\hline & 10.4Airport density \\
\hline \multirow[t]{4}{*}{ 11. Ground and Port Infrastructure } & 11.1Quality of roads \\
\hline & 11.2Road density \\
\hline & 11.3Paved road density \\
\hline & 11.4Quality of port infrastructure \\
\hline \multirow[t]{3}{*}{ 12. Tourist Service Infrastructure } & 12.1 Hotel rooms \\
\hline & 12.2 Presence of major car rental companies \\
\hline & 12.3 Automated teller machines per adult population \\
\hline Natural and Cultural Resources & \\
\hline \multirow[t]{4}{*}{ 13. Natural Resources } & 13.1 Number of World Heritage natural sites \\
\hline & 13.2 Total known species \\
\hline & 13.3 Total protected areas \\
\hline & 13.4Attractiveness of natural assets \\
\hline \multirow[t]{3}{*}{ 14. Cultural Resources \& Business Travel } & 4.1 Number of World Heritage cultural sites \\
\hline & 14.2 Number of oral \&intangible cultural heritage expression \\
\hline & 14.3 Number of large sports stadiums \\
\hline
\end{tabular}

\section{The variable and measurement}

This study is trying to examine the competitiveness of new development ten tourist destinations' performance in Indonesia. According to the program from the Minister of Tourism Republic Indonesia, the new development ten tourist destinations are Lake Toba in North Sumatra, Tanjung Kelayang in Bangka Belitung, Tanjung Lesung in Banten, Thousand Islands regency in Jakarta, Borobudur in Central Java, the areas of Bromo, Tengger and Semeru in East Java, Mandalika in West Nusa Tenggara, Labuan Bajo in East Nusa Tenggara, Wakatobi in Southeast Sulawesi and Morotai in North Maluku. And based on Travel and tourism competitiveness index from World Economic Forum. The T\&T Competitiveness 
Index measures four broad factors of competitiveness. These factors are organized into sub-indexes, which are further divided into 14 pillars: A).The Enabling Environment sub index, which captures the general settings necessary for operating in a country: 1.Business Environment, 2.Safety and Security,3.Health and Hygiene, 4.Human Resources and Labour Market, 5.ICT Readiness. B).The T\&T Policy and Enabling Conditions sub index, which captures specific policies or strategic aspects that impact the T\&T industry more directly: 6.Prioritization of Travel and Tourism, 7.International Openness, 8.Price Competitiveness, 9.Environmental Sustainability. C). The Infrastructure sub index, which captures the availability and quality of physical infrastructure of each economy: 10.Air Transport Infrastructure, 11.Ground and Port Infrastructure, 12.Tourist Service Infrastructure. D). The Natural and Cultural Resources sub index, which captures the principal "reasons to travel": 13.Natural Resources, 14.Cultural Resources and Business Travel. Based on (Ridwan, 2007)The Ordinal scale is a scale built on the rank, how to sort all objects high to the lowest level or vice versa. In this study, researchers used 10 Point Numerical Rating Scale in data. The lowest scores is 1 and the highest scores is 10.

TABLE II, VARIABLE AND MEASUREMENT

\begin{tabular}{|c|c|c|c|}
\hline Variable & Indicator & $\begin{array}{c}\text { Scale of } \\
\text { Measurement }\end{array}$ & Source \\
\hline \multicolumn{4}{|l|}{ Enabling Environment } \\
\hline 1.Business Environment & $\begin{array}{l}\text { 1.1 Impact of rules on FDI } \\
\text { 1.2 Time required to deal with construction permit } \\
\text { 1.3 Time to start a business } \\
\text { 1.4 Cost to start a business } \\
\text { 1.5 Total tax rate }\end{array}$ & $\begin{array}{c}\text { Ordinal } \\
(1-10)\end{array}$ & $\begin{array}{l}\text { Ridwan } \\
\text { (2007) }\end{array}$ \\
\hline 2.Safety and Security & $\begin{array}{l}\text { 2.1 Business costs of crime and violence } \\
\text { 2.2 Reliability of police services } \\
\text { 2.3 Homicide rate }\end{array}$ & $\begin{array}{c}\text { Ordinal } \\
(1-10)\end{array}$ & $\begin{array}{l}\text { Ridwan } \\
(2007)\end{array}$ \\
\hline 3.Health and Hygiene & $\begin{array}{l}\text { 3.1 Physician density } \\
\text { 3.2 Access to improved sanitation } \\
\text { 3.3 Access to improved drinking water } \\
\text { 3.4 Hospital beds } \\
\text { 3.5 HIV prevalence } \\
\text { 3.6 Malaria incidence }\end{array}$ & $\begin{array}{c}\text { Ordinal } \\
(1-10)\end{array}$ & $\begin{array}{l}\text { Ridwan } \\
(2007)\end{array}$ \\
\hline $\begin{array}{r}\text { 4.Human Resource \& } \\
\text { Labour Market }\end{array}$ & $\begin{array}{l}\text { Qualification of the labour force : } \\
\text { 4.1 Primary education enrolment rate } \\
\text { 4.2 Secondary education enrolment rate } \\
\text { Labour market: } \\
\text { 4.3 Ease of finding skilled employees } \\
\text { 4.4 Pay and productivity } \\
\text { 4.5 Female labour force participation }\end{array}$ & $\begin{array}{c}\text { Ordinal } \\
(1-10)\end{array}$ & $\begin{array}{l}\text { Ridwan } \\
(2007)\end{array}$ \\
\hline 5.ICT Readiness & $\begin{array}{l}\text { 5.1 Internet use for business-to-consumer transaction } \\
\text { 5.2 Individuals using the internet } \\
\text { 5.3 Mobile telephone subscriptions } \\
\text { 5.4 Mobile network coverage } \\
\text { 5.5 Quality of electricity supply }\end{array}$ & $\begin{array}{c}\text { Ordinal } \\
(1-10)\end{array}$ & $\begin{array}{l}\text { Ridwan } \\
(2007)\end{array}$ \\
\hline \multicolumn{4}{|l|}{$\begin{array}{c}\text { T\&T Policy and } \\
\text { Enabling Conditions }\end{array}$} \\
\hline $\begin{array}{l}\text { 6.Prioritization of } \\
\text { Travel \& Tourism }\end{array}$ & $\begin{array}{l}\text { 6.1 Government prioritization of travel \& tourism } \\
\text { industry } \\
\text { 6.2 T\&T government expenditure } \\
6.3 \text { Effectiveness of marketing to attract tourists } \\
\text { 6.4 Country Brand Strategy rating }\end{array}$ & $\begin{array}{c}\text { Ordinal } \\
(1-10)\end{array}$ & $\begin{array}{l}\text { Ridwan } \\
(2007)\end{array}$ \\
\hline 7.InternationalOpenness & 7.1 Visa requirements & $\begin{array}{l}\text { Ordinal } \\
(1-10)\end{array}$ & $\begin{array}{c}\text { Ridwan } \\
(2007)\end{array}$ \\
\hline
\end{tabular}




\begin{tabular}{|c|c|c|c|}
\hline Variable & Indicator & $\begin{array}{c}\text { Scale of } \\
\text { Measurement }\end{array}$ & Source \\
\hline \multicolumn{4}{|l|}{ Enabling Environment } \\
\hline 8.Price Competitiveness & $\begin{array}{l}\text { 8.1 } \text { Ticket taxes and airport charges } \\
\text { 8.2 Purchasing power parity } \\
\text { 8.3 Fuel price levels }\end{array}$ & $\begin{array}{c}\text { Ordinal } \\
(1-10)\end{array}$ & $\begin{array}{l}\text { Ridwan } \\
\text { (2007) }\end{array}$ \\
\hline $\begin{array}{l}\text { 9.Environmental } \\
\text { Sustainability }\end{array}$ & $\begin{array}{l}\text { 9.1 Sustainability of travel \& tourism industry } \\
\text { development } \\
\text { 9.2 Particulate matter (2.5) concentration } \\
\text { 9.3 Baseline water stress } \\
\text { 9.4 Forest cover change } \\
\text { 9.5 Wastewater treatment } \\
\text { 9.6 Coastal shelf fishing pressure }\end{array}$ & $\begin{array}{l}\text { Ordinal } \\
(1-10)\end{array}$ & $\begin{array}{l}\text { Ridwan } \\
\text { (2007) }\end{array}$ \\
\hline \multicolumn{4}{|l|}{ Infrastructure } \\
\hline $\begin{array}{l}\text { 10.Air Transport } \\
\text { Infrastructure }\end{array}$ & $\begin{array}{l}\text { 10.1 Available seat kilometers, Domestic } \\
\text { 10.2 Available seat kilometers, International } \\
\text { 10.3 Aircraft departures } \\
\text { 10.4 Airport density }\end{array}$ & $\begin{array}{l}\text { Ordinal } \\
(1-10)\end{array}$ & $\begin{array}{l}\text { Ridwan } \\
\text { (2007) }\end{array}$ \\
\hline $\begin{array}{l}\text { 11.Ground and Port } \\
\text { Infrastructure }\end{array}$ & $\begin{array}{l}\text { 11.1 Quality of roads } \\
\text { 11.2 Road density } \\
\text { 11.3 Paved road density } \\
\text { 11.4 Quality of port infrastructure }\end{array}$ & $\begin{array}{l}\text { Ordinal } \\
(1-10)\end{array}$ & $\begin{array}{l}\text { Ridwan } \\
\text { (2007) }\end{array}$ \\
\hline $\begin{array}{l}\text { 12.Tourist Service } \\
\text { Infrastructure }\end{array}$ & $\begin{array}{l}\text { 12.1 Hotel rooms } \\
\text { 12.2 Presence of major car rental Companies } \\
\text { 12.3 Automated teller machines per adult pop }\end{array}$ & $\begin{array}{l}\text { Ordinal } \\
(1-10)\end{array}$ & $\begin{array}{l}\text { Ridwan } \\
(2007)\end{array}$ \\
\hline \multicolumn{4}{|l|}{$\begin{array}{c}\text { Natural and Cultural } \\
\text { Resources }\end{array}$} \\
\hline 13.Natural Resources & $\begin{array}{l}\text { 13.1 Number of World Heritage natural sites } \\
\text { 13.2 Total known species } \\
\text { 13.3 Total protected areas } \\
\text { 13.4 Attractiveness of natural assets }\end{array}$ & $\begin{array}{l}\text { Ordinal } \\
(1-10)\end{array}$ & $\begin{array}{l}\text { Ridwan } \\
\text { (2007) }\end{array}$ \\
\hline $\begin{array}{l}\text { 14.Cultural Resources } \\
\text { \& Business Travel }\end{array}$ & $\begin{array}{l}\text { 14.1 Number of World Heritage cultural sites } \\
\text { 14.2 Number of oral \& intangible cultural heritage } \\
\text { expressions } \\
\text { 14.3 Number of large sports stadiums }\end{array}$ & $\begin{array}{c}\text { Ordinal } \\
(1-10)\end{array}$ & $\begin{array}{l}\text { Ridwan } \\
\text { (2007) }\end{array}$ \\
\hline
\end{tabular}

\section{Data collection procedure}

The research focuses use secondary data. Hox and Boeije (2005) defined that secondary data is data originally collected for a different purpose and reused for another research question. Well-documented data sets come with a detailed description of the methods and procedures used to collect the data. The data in this research is $\mathbf{5 6}$ observations, from 10 tourist destinations. Secondary data is "data which collected by person or other institutions such as annual report, company profile and so on." The quantitative data that would be used in this study are numeric data.(Kusmayadi and Sugiarto, 2000).

This research to know the competitiveness of new development ten tourist destinations' performance in Indonesia. The research project will, therefore, seek to explore and investigate the following:

1. How competitive business environment performance on new development ten tourist destinations in Indonesia.

2. How competitive safety and security performance on new development ten tourist destinations in Indonesia.

3. How competitive health and hygiene performance on new development ten tourist destinations in Indonesia. 
4. How competitive human resource and labour market performance on new development ten tourist destinations in Indonesia.

5. How competitive ICT readiness performance on new development ten tourist destinations in Indonesia.

6. How competitive prioritization of travel \& tourism performance on new development ten tourist destinations in Indonesia.

7. How competitive international openness performance on new development ten tourist destinations in Indonesia.

8. How competitive price competitiveness performance on new development ten tourist destinations in Indonesia.

9. How competitive environmental sustainability performance on new development ten tourist destinations in Indonesia.

10. How competitive air transport infrastructure performance on new development ten tourist destinations in Indonesia.

11. How competitive ground and port infrastructure performance on new development ten tourist destinations in Indonesia.

12. How competitive tourist service infrastructure performance on new development ten tourist destinations in Indonesia.

13. How competitive natural resources performance on new development ten tourist destinations in Indonesia.

14. How competitive cultural resources \& business travel performance on new development ten tourist destinations in Indonesia.

\section{E. Method of data analysis}

The Ordinal scale is a scale built on the rank, how to sort all objectshigh to the lowest level or vice versa. (Ridwan, 2007:84). In this study, researchers used 10 Point Numerical Rating Scale in data. The lowest scores is 1 and the highest scores is 10. A higher data indicates a higher score are indicator 1.1 Impact of rules on FDI,1.4 Cost to start a business, 1.5 Total tax rate, 2.2 Reliability of police services, 3.1 Physician density, 3.2 Access to improved sanitation, 3.3 Access to improved drinking water, 3.4 Hospital beds, 4.1 Primary education enrolment rate, 4.2 Secondary education enrolment rate, 4.3 Ease of finding skilled employees, 4.4 Pay and productivity, 4.5 Female labour force participation, 5.1 Internet use for business-to-consumer transactions, 5.2 Individuals using the internet, 5.3 Mobile telephone subscriptions, 5.4 Mobile network coverage, 5.5 Quality of electricity supply, 6.1 Government prioritization of travel and tourism industry, 6.2 T\&T government expenditure, 6.3 Effectiveness of marketing to attract tourists, 6.4 Country Brand Strategy rating, 8.2 Purchasing power parity, 9.1 Sustainability of travel and tourism industry development, 9.2 Particulate matter (2.5) concentration,9.4 Forest cover change, 9.5 Wastewater treatment, 10.1 Available seat kilometers, domestic, 10.2 Available seat kilometers, international, 10.3 Aircraft departures, 10.4 Airport density, 11.1 Quality of roads, 11.2 Road density, 11.3 Paved road density, 12.1 Hotel rooms, 12.2 Presence of major car rental companies, 12.3 Automated teller machines per adult Population, 13.2 Total known species, 13.3 Total protected areas, 13.4 Attractiveness of natural assets. And a higher data indicates a lower score are indicator 1.2 Time required to deal with construction permits, 1.3 Time to start a business, 2.1 Businesscosts of crime and violence, 2.3 Homicide rate, 3.5 HIV prevalence, 3.6 Malaria incidence, 8.1 Ticket taxes and airport charges, 9.6 Coastal shelf fishing pressure. With the exception of the unique indicator for score are 7.1 Visa requirements, 8.3 Fuel price levels, 9.3 Baseline water stress, 11.4 Quality of port infrastructure, 13.1 Number of World Heritage natural sites, 14.1 Number of World Heritage cultural sites, 14.2 Number of oral and intangible cultural heritage expressions, 14.3 Number of large sports stadiums. After that researcher analyze the data for this study, the statistical software SPSS version 20.0, was used as the instrument for the dataanalysis. 


\section{RESULT AND DISCUSSION}

The purpose of research will focus on four broad factors of competitiveness from new development 10 tourist destinations' performance in Indonesia. These factors are organized into subindexes, which are further divided into 14 pillars: A).The Enabling Environment sub index, which captures the general settings necessary for operating in a country: 1.Business Environment, 2.Safety and Security,3.Health and Hygiene, 4.Human Resources and Labour Market, 5.ICT Readiness. B).The T\&T Policy and Enabling Conditions sub index, which captures specific policies or strategic aspects that impact the T\&T industry more directly: 6.Prioritization of Travel and Tourism, 7.International Openness, 8.Price Competitiveness, 9.Environmental Sustainability. C).The Infrastructure sub index, which captures the availability and quality of physical infrastructure of each economy: 10.Air Transport Infrastructure, 11.Ground and Port Infrastructure, 12.Tourist Service Infrastructure. D). The Natural and Cultural Resources sub index, which captures the principal "reasons to travel": 13.Natural Resources, 14.Cultural Resources and Business Travel.

\section{A. Profile of the respondents}

The research was conducted by using secondary data which is using 56 observations, from new development 10 tourist destinations.

\section{B. Finding for The Research Objectives}

\section{The Enabling Environment}

Firstly it was conducted the descriptive statistic to see the competitiveness of business environment from new development 10 tourist destinations' performance in Indonesia.

TABLE III. BUSINESS ENVIRONMENT

\begin{tabular}{lcccc}
\hline Province & N & Minimum & Maximum & Mean \\
\hline North Sumatra & 5 & 3 & 10 & 6.40 \\
Bangka Belitung & 5 & 0 & 3 & 1.00 \\
Banten & 5 & 0 & 9 & 4.60 \\
Jakarta & 5 & 6 & 10 & 8.20 \\
Central Java & 5 & 5 & 10 & 7.80 \\
East Java & 5 & 7 & 10 & 8.40 \\
West Nusa Tenggara & 5 & 5 & 9 & 6.60 \\
East Nusa Tenggara & 5 & 0 & 4 & 2.00 \\
Southeast Sulawesi & 5 & 0 & 8 & 2.60 \\
North Maluku & 5 & 0 & 4 & 1.40 \\
\hline
\end{tabular}

From the descriptive statistic above for business environment, the highest is East Java with Mean 8.40, the second highest is Jakarta with Mean 8.20, the third highest is Central Java with Mean 7.80, the fourth highest is West Nusa Tenggara with Mean 6.60, the fifth highest is North Sumatra with Mean 6.40,the lowest is Bangka Belitung with Mean 1.00,the second lowest is North Maluku with Mean 1.40, the third lowest is East Nusa Tenggara with Mean 2.00, the fourth lowest is Southeast Sulawesi with Mean 2.60, the fifth lowest is Banten with Mean 4.60.

Secondly it was conducted the descriptive statistic to see the competitiveness of safety and security from new development 10 tourist destinations' performance in Indonesia. 
TABLE IV SAFETY AND SECURITY

\begin{tabular}{lcccc}
\hline Province & N & Minimum & Maximum & Mean \\
\hline North Sumatra & 3 & 1 & 6 & 3.00 \\
Bangka Belitung & 3 & 1 & 9 & 6.33 \\
Banten & 3 & 5 & 10 & 7.33 \\
Jakarta & 3 & 1 & 7 & 3.33 \\
Central Java & 3 & 4 & 10 & 6.33 \\
East Java & 3 & 3 & 8 & 4.67 \\
West Nusa Tenggara & 3 & 5 & 9 & 6.67 \\
East Nusa Tenggara & 3 & 4 & 6 & 4.67 \\
Southeast Sulawesi & 3 & 2 & 9 & 6.33 \\
North Maluku & 3 & 3 & 10 & 6.67 \\
\hline
\end{tabular}

From the descriptive statistic above for safety and security, the highest is Banten with Mean 7.33, the second highest is West Nusa Tenggara and North Maluku with Mean 6.67, the third highest is Bangka Belitung, Central Java and Southeast Sulawesi with Mean 6.33, the fourth highest is East Java and East Nusa Tenggara with Mean 4.67, the lowest is North Sumatra with Mean 3.00, the second lowest is Jakarta with Mean 3.33. Thirdly it was conducted the descriptive statistic to see the competitiveness of health and hygiene from new development 10 tourist destinations' performance in Indonesia.

\begin{tabular}{lcccc}
\multicolumn{5}{c}{ TABLE V, HEALTH AND HYGIENE } \\
\hline Province & $\mathrm{N}$ & Minimum & Maximum & Mean \\
\hline North Sumatra & 6 & 4 & 9 & 6.33 \\
Bangka Belitung & 6 & 2 & 9 & 5.17 \\
Banten & 6 & 3 & 10 & 6.33 \\
Jakarta & 6 & 2 & 10 & 8.00 \\
Central Java & 6 & 3 & 9 & 6.50 \\
East Java & 6 & 1 & 10 & 6.67 \\
West Nusa Tenggara & 6 & 5 & 7 & 5.33 \\
East Nusa Tenggara & 6 & 1 & 6 & 2.83 \\
Southeast Sulawesi & 6 & 3 & 9 & 5.00 \\
North Maluku & 6 & 1 & 10 & 3.00 \\
\hline
\end{tabular}

From the descriptive statistic above for health and hygiene, the highest is Jakarta with Mean 8.00, the second highest is East Java with Mean 6.67, the third highest is Central Java with Mean 6.50, the fourth highest is North Sumatra and Banten with Mean 6.33, the fifth highest is West Nusa Tenggara with Mean 5.33, the lowest is East Nusa Tenggara with Mean 2.83, the second lowest is North Maluku with Mean 3.00, the third lowest is Southeast Sulawesi with Mean 5.00, the fourth lowest is Bangka Belitung with Mean 5.17. Fourthly it was conducted the descriptive statistic to see the competitiveness of human resources and labour market from new development 10 tourist destinations' performance in Indonesia.

TABLE VI, HUMAN RESOURCES AND LABOUR MARKET

\begin{tabular}{lcccc}
\hline Province & N & Minimum & Maximum & Mean \\
\hline North Sumatra & 5 & 3.00 & 10.00 & 7.40 \\
Bangka Belitung & 5 & 2.00 & 9.00 & 5.00 \\
Banten & 5 & 3.00 & 9.00 & 6.80 \\
Jakarta & 5 & 4.00 & 10.00 & 7.60 \\
Central Java & 5 & 1.00 & 7.00 & 4.60 \\
East Java & 5 & 2.00 & 9.00 & 6.80 \\
West Nusa Tenggara & 5 & 1.00 & 10.00 & 5.40 \\
East Nusa Tenggara & 5 & 1.00 & 6.00 & 2.40 \\
Southeast Sulawesi & 5 & 2.00 & 8.00 & 4.80 \\
North Maluku & 5 & 2.00 & 6.00 & 4.40 \\
\hline
\end{tabular}


From the descriptive statistic above for human resources and labour market, the highest is Jakarta with Mean 7.60, the second highest is North Sumatra with Mean 7.40, the third highest is Banten and East Java with Mean 6.80, the fourth highest is West Nusa Tenggara with Mean 5.40, the fifth highest is Bangka Belitung with Mean 5.00, the lowest is East Nusa Tenggara with Mean 2.40, the second lowest is North Maluku with Mean 4.40, the third lowest is Central Java with Mean 4.60, the fourth lowest is Southeast Sulawesi with Mean 4.80. Fifthly it was conducted the descriptive statistic to see the competitiveness of ICT readiness from new development 10 tourist destinations' performance in Indonesia.

TABLE VII, CT READINESS

\begin{tabular}{lcccc}
\hline Province & N & Minimum & Maximum & Mean \\
\hline North Sumatra & 5 & 3 & 6 & 4.20 \\
Bangka Belitung & 5 & 5 & 9 & 7.60 \\
Banten & 5 & 6 & 9 & 7.60 \\
Jakarta & 5 & 10 & 10 & 10.00 \\
Central Java & 5 & 4 & 9 & 6.80 \\
East Java & 5 & 4 & 8 & 6.40 \\
West Nusa Tenggara & 5 & 3 & 6 & 4.40 \\
East Nusa Tenggara & 5 & 1 & 3 & 1.40 \\
Southeast Sulawesi & 5 & 2 & 7 & 3.80 \\
North Maluku & 5 & 1 & 7 & 2.80 \\
\hline
\end{tabular}

From the descriptive statistic above, the highest ICT readiness is Jakarta with Mean 10.00, the second highest ICT readiness is Bangka Belitung and Banten with Mean 7.60, the third highest ICT readiness is Central Java with Mean 6.80, the fourth highest ICT readiness is East Java with Mean 6.40, the fifth highest ICT readiness is West Nusa Tenggara with Mean 4.40, the lowest ICT readiness is East Nusa Tenggara with Mean 1.40, the second lowest ICT readiness is North Maluku with Mean 2.80, the third lowest ICT readiness is Southeast Sulawesi with Mean 3.80, the fourth lowest ICT readiness is North Sumatra with Mean 4.20.

\section{The T\&T Policy and Enabling Conditions}

Firstly it was conducted the descriptive statistic to see the competitiveness of prioritization of travel and tourism from new development 10 tourist destinations' performance in Indonesia.

\section{TABLE VIII, PRIORITIZATION OF TRAVEL AND TOURISM}

\begin{tabular}{lcccc}
\hline Province & N & Minimum & Maximum & Mean \\
\hline North Sumatra & 4 & 6 & 7 & 6.25 \\
Bangka Belitung & 4 & 2 & 7 & 4.00 \\
Banten & 4 & 2 & 8 & 5.25 \\
Jakarta & 4 & 9 & 10 & 9.75 \\
Central Java & 4 & 3 & 8 & 6.25 \\
East Java & 4 & 5 & 10 & 8.25 \\
West Nusa Tenggara & 4 & 5 & 9 & 6.75 \\
East Nusa Tenggara & 4 & 1 & 8 & 4.00 \\
Southeast Sulawesi & 4 & 2 & 4 & 3.00 \\
North Maluku & 4 & 1 & 3 & 1.50 \\
\hline
\end{tabular}

From the descriptive statistic above, the highest prioritization of travel and tourism is Jakarta with Mean 9.75, the second highest prioritization of travel and tourism is East Java with Mean 8.25, the third highest prioritization of travel and tourism is West Nusa Tenggara with Mean 6.75, the fourth highest prioritization of travel and tourism is North Sumatra and Central Java with Mean 6.25, the fifth highest prioritization of travel and tourism is Banten with Mean 5.25, the lowest prioritization of travel and tourism is North Maluku with Mean 1.50, the second lowest prioritization of travel and tourism is Southeast Sulawesi with Mean 3.00, the third lowest prioritization of travel and tourism is Bangka Belitung and East Nusa Tenggara with Mean 4.00, Secondly it was conducted the descriptive statistic to 
see the competitiveness of International Openness from new development 10 tourist destinations' performance in Indonesia.

TABLE IX, INTERNATIONAL OPENNESS

\begin{tabular}{lcccc}
\hline Province & N & Minimum & Maximum & Mean \\
\hline North Sumatra & 1 & 10 & 10 & 10.00 \\
Bangka Belitung & 1 & 10 & 10 & 10.00 \\
Banten & 1 & 10 & 10 & 10.00 \\
Jakarta & 1 & 10 & 10 & 10.00 \\
Central Java & 1 & 10 & 10 & 10.00 \\
East Java & 1 & 10 & 10 & 10.00 \\
West Nusa Tenggara & 1 & 10 & 10 & 10.00 \\
East Nusa Tenggara & 1 & 10 & 10 & 10.00 \\
Southeast Sulawesi & 1 & 10 & 10 & 10.00 \\
North Maluku & 1 & 10 & 10 & 10.00 \\
\hline
\end{tabular}

From the descriptive statistic above, all data have the same value ten. Thirdly it was conducted the descriptive statistic to see the competitiveness of price competitiveness from new development 10 tourist destinations' performance in Indonesia.

TABLE X, PRICE COMPETITIVENESS

\begin{tabular}{lcccc}
\hline Province & N & Minimum & Maximum & Mean \\
\hline North Sumatra & 3 & 4 & 10 & 8.00 \\
Bangka Belitung & 3 & 3 & 10 & 6.67 \\
Banten & 3 & 5 & 10 & 8.00 \\
Jakarta & 3 & 9 & 10 & 9.67 \\
Central Java & 3 & 1 & 10 & 6.33 \\
East Java & 3 & 8 & 10 & 9.33 \\
West Nusa Tenggara & 3 & 6 & 9 & 7.00 \\
East Nusa Tenggara & 3 & 3 & 7 & 5.33 \\
Southeast Sulawesi & 3 & 0 & 9 & 5.00 \\
North Maluku & 3 & 0 & 3 & 1.67 \\
\hline
\end{tabular}

From the descriptive statistic above, the highest price competitiveness is Jakarta with Mean 9.67, the second highest price competitiveness is East Java with Mean 9.33, the third highest price competitiveness is North Sumatra and Central Java with Mean 8.00, the fourth highest price competitiveness is West Nusa Tenggara with Mean 7.00, the fifth highest price competitiveness is Bangka Belitung with Mean 6.67, the lowest price competitiveness is North Maluku with Mean 1.67, the second lowest price competitiveness is Southeast Sulawesi with Mean 5.00, the third lowest price competitiveness is East Nusa Tenggara with Mean 5.33, the fourth lowest price competitiveness is Central Java with Mean 6.33. Fourthly it was conducted the descriptive statistic to see the competitiveness of environmental sustainability from new development 10 tourist destinations' performance in Indonesia.

\begin{tabular}{lcccc}
\multicolumn{5}{c}{ TABLE XI, ENVIRONMENTAL SUSTAINABILITY } \\
\hline Province & $\mathrm{N}$ & Minimum & Maximum & Mean \\
\hline North Sumatra & 6 & 1 & 9 & 4.50 \\
Bangka Belitung & 6 & 1 & 10 & 5.00 \\
Banten & 6 & 2 & 9 & 4.83 \\
Jakarta & 6 & 1 & 10 & 2.50 \\
Central Java & 6 & 1 & 5 & 3.00 \\
East Java & 6 & 1 & 8 & 4.33 \\
West Nusa Tenggara & 6 & 1 & 8 & 5.00 \\
East Nusa Tenggara & 6 & 1 & 10 & 5.67 \\
Southeast Sulawesi & 6 & 1 & 9 & 6.33 \\
North Maluku & 6 & 1 & 10 & 7.17 \\
\hline
\end{tabular}


From the descriptive statistic above, the highest environmental sustainability is North Maluku with Mean 7.17, the second highest environmental sustainability is Southeast Sulawesi with Mean 6.33, the third highest environmental sustainability is East Nusa Tenggara with Mean 5.67, the fourth highest environmental sustainability is Bangka Belitung and West Nusa Tenggara with Mean 5.00, the fifth highest environmental sustainability is Banten with Mean 4.83, the lowest environmental sustainability is Jakarta with Mean 2.50, the second lowest environmental sustainability is Central Java with Mean 3.00, the third lowest environmental sustainability is East Java with Mean 4.33, the fourth lowest environmental sustainability is North Sumatra with Mean 4.50.

\section{The Infrastructure}

Firstly it was conducted the descriptive statistic to see the competitiveness of air transport infra structure from new development 10 tourist destinations' performance in Indonesia.

TABLE XII, AIR TRANSPORT INFRASTRUCTURE

\begin{tabular}{lcccc}
\hline Province & N & Minimum & Maximum & Mean \\
\hline North Sumatra & 4 & 8 & 8 & 8.00 \\
Bangka Belitung & 4 & 0 & 3 & 2.25 \\
Banten & 4 & 10 & 10 & 10.00 \\
Jakarta & 4 & 5 & 6 & 5.50 \\
Central Java & 4 & 6 & 7 & 6.50 \\
East Java & 4 & 9 & 9 & 9.00 \\
West Nusa Tenggara & 4 & 4 & 7 & 5.25 \\
East Nusa Tenggara & 4 & 4 & 7 & 4.75 \\
Southeast Sulawesi & 4 & 0 & 2 & 1.50 \\
North Maluku & 4 & 0 & 1 & .75 \\
\hline
\end{tabular}

From the descriptive statistic above, the highest air transport infrastructure is Banten with Mean 10.00, the second highest air transport infrastructure is East Java with Mean 9.00, the third highest air transport infrastructure is North Sumatra with Mean 8.00, the fourth highest air transport infrastructure is Central Java with Mean 6.50, the fifth highest air transport infrastructure is Jakarta with Mean 5.50, the lowest air transport infrastructure is North Maluku with Mean 0.75, the second lowest air transport infrastructure is Southeast Sulawesi with Mean 1.50, the third lowest air transport infrastructure is Bangka Belitung with Mean 2.25, the fourth lowest air transport infrastructure is East Nusa Tenggara with Mean 4.75, the fifth lowest air transport infrastructure is West Nusa Tenggara with Mean 5.25.

Secondly it was conducted the descriptive statistic to see the competitiveness of ground and port infrastructure from new development 10 tourist destinations' performance in Indonesia.

TABLE XIII, GROUND AND PORT INFRASTRUCTURE

\begin{tabular}{lcccc}
\hline Province & N & Minimum & Maximum & Mean \\
\hline North Sumatra & 4 & 2 & 6 & 4.25 \\
Bangka Belitung & 4 & 2 & 9 & 4.25 \\
Banten & 4 & 2 & 10 & 6.50 \\
Jakarta & 4 & 1 & 10 & 6.25 \\
Central Java & 4 & 2 & 9 & 6.75 \\
East Java & 4 & 1 & 8 & 6.25 \\
West Nusa Tenggara & 4 & 0 & 5 & 3.25 \\
East Nusa Tenggara & 4 & 1 & 5 & 3.25 \\
Southeast Sulawesi & 4 & 2 & 6 & 3.00 \\
North Maluku & 4 & 1 & 2 & 1.50 \\
\hline
\end{tabular}

From the descriptive statistic above, the highest ground and port infrastructure is Central Java with Mean 6.75, the second highest ground and port infrastructure is Banten with Mean 6.50, the third highest ground and port infrastructure is Jakarta and East Java with Mean 6.25, the fourth highest ground and port 
infrastructure is North Sumatra and Bangka Belitung with Mean 4.25, the lowest ground and port infrastructure is North Maluku with Mean 1.50, the second lowest ground and port infrastructure is Southeast Sulawesi with Mean 3.00, the third lowest ground and port infrastructure is West Nusa Tenggara and East Nusa Tenggara with Mean 3.25.

Thirdly it was conducted the descriptive statistic to see the competitiveness of tourist service infrastructure from new development 10 tourist destinations' performance in Indonesia.

TABLE XIV, TOURIST SERVICE INFRASTRUCTURE

\begin{tabular}{lcccc}
\hline Province & N & Minimum & Maximum & Mean \\
\hline North Sumatra & 3 & 6 & 7 & 6.67 \\
Bangka Belitung & 3 & 2 & 6 & 3.67 \\
Banten & 3 & 5 & 7 & 6.33 \\
Jakarta & 3 & 9 & 10 & 9.33 \\
Central Java & 3 & 8 & 8 & 8.00 \\
East Java & 3 & 9 & 10 & 9.67 \\
West Nusa Tenggara & 3 & 5 & 7 & 6.00 \\
East Nusa Tenggara & 3 & 0 & 4 & 2.67 \\
Southeast Sulawesi & 3 & 2 & 5 & 3.33 \\
North Maluku & 3 & 0 & 1 & .67 \\
\hline
\end{tabular}

From the descriptive statistic above, the highest tourist service infrastructure is East Java with Mean 9.67, the second highest tourist service infrastructure is Jakarta with Mean 9.33, the third highest tourist service infrastructure is Central Java with Mean 8.00, the fourth highest tourist service infrastructure is North Sumatra with Mean 6.67, the fifth highest tourist service infrastructure is Banten with Mean 6.33, the lowest tourist service infrastructure is North Maluku with Mean 0.67, the second lowest tourist service infrastructure is East Nusa Tenggara with Mean 2.67, the third lowest tourist service infrastructure is Southeast Sulawesi with Mean 3.33, the fourth lowest tourist service infrastructure is Bangka Belitung with Mean 3.67, the fifth lowest tourist service infrastructure is West Nusa Tenggara with Mean 6.00.

\section{Natural and Cultural Resources}

Firstly it was conducted the descriptive statistic to see the competitiveness of natural resources from new development 10 tourist destinations' performance in Indonesia.

\begin{tabular}{lcccc}
\multicolumn{5}{c}{ Table XV, Natural Resources } \\
\hline Province & $\mathrm{N}$ & Minimum & Maximum & Mean \\
\hline North Sumatra & 4 & 1 & 8 & 5.75 \\
Bangka Belitung & 4 & 0 & 6 & 3.25 \\
Banten & 4 & 1 & 10 & 4.50 \\
Jakarta & 4 & 0 & 3 & 1.25 \\
Central Java & 4 & 0 & 10 & 3.25 \\
East Java & 4 & 0 & 10 & 5.50 \\
West Nusa Tenggara & 4 & 1 & 7 & 4.50 \\
East Nusa Tenggara & 4 & 0 & 9 & 5.00 \\
Southeast Sulawesi & 4 & 0 & 9 & 4.50 \\
North Maluku & 4 & 0 & 8 & 4.50 \\
\hline
\end{tabular}

From the descriptive statistic above, the highest natural resources is North Sumatra with Mean 5.75, the second highest natural resources is East Java with Mean 5.50, the third highest natural resources is East Nusa Tenggara with Mean 5.00, the fourth highest natural resources is Banten, West Nusa Tenggara, Southeast Sulawesi and North Maluku with Mean 4.50, the lowest natural resources is Jakarta with Mean 1.25, the second lowest natural resources is Bangka Belitung and Central Java with Mean 3.25. 
Secondly it was conducted the descriptive statistic to see the competitiveness of cultural resources \& business travel from new development 10 tourist destinations' performance in Indonesia.

TABLE XVI, CULTURAL RESOURCES \& BUSINESS TRAVEL

\begin{tabular}{lcccc}
\hline Province & N & Minimum & Maximum & Mean \\
\hline North Sumatra & 3 & 0 & 1 & .33 \\
Bangka Belitung & 3 & 0 & 1 & .33 \\
Banten & 3 & 0 & 2 & 1.00 \\
Jakarta & 3 & 0 & 3 & 1.33 \\
Central Java & 3 & 3 & 4 & 3.33 \\
East Java & 3 & 0 & 8 & 4.00 \\
West Nusa Tenggara & 3 & 0 & 3 & 1.00 \\
East Nusa Tenggara & 3 & 0 & 1 & .33 \\
Southeast Sulawesi & 3 & 0 & 2 & .67 \\
North Maluku & 3 & 0 & 1 & .33 \\
\hline
\end{tabular}

From the descriptive statistic above, the highest cultural resources \& business travel is East Java with Mean 4.00, the second highest cultural resources \& business travel is Central Java with Mean 3.33, the third highest cultural resources \& business travel is Jakarta with Mean 1.33, the fourth highest cultural resources \& business travel is Banten and West Nusa Tenggara with Mean 1.00, the lowest cultural resources \& business travel is North Sumatra, Bangka Belitung, East Nusa Tenggara and North Maluku with Mean 0.33, the second lowest cultural resources \& business travel is Southeast Sulawesi with Mean 0.67 .

TABLE XVII, THE COMPETITIVENESS OF NEW DEVELOPMENT TEN TOURIST
\begin{tabular}{ccc}
\multicolumn{4}{c}{ DESTINATIONS IN INDONESIA } \\
\cline { 2 - 4 } Province & Rank & Score \\
\hline North Sumatra & 5 & 5.500 \\
Bangka Belitung & 7 & 4.155 \\
Banten & 2 & 5.978 \\
Jakarta & 3 & 5.931 \\
Central Java & 4 & 5.794 \\
East Java & 1 & 6.906 \\
West Nusa Tenggara & 6 & 5.113 \\
East Nusa Tenggara & 9 & 3.783 \\
Southeast Sulawesi & 8 & 3.946 \\
North Maluku & 10 & 3.032 \\
\hline
\end{tabular}

From the table above,the rank of new development tourist destinations will be number ten is North Maluku with score 3.032, number nine is East Nusa Tenggara with score 3.783, number eight is Southeast Sulawesi with score 3.946, number seven is Bangka Belitung with score 4.155, number six is West Nusa Tenggara with score 5.113, number five is North Sumatra with score 5.500, number four is Central Java with score 5.794, number three is Jakarta with score 5.931, number two is Banten with score 5.978 and number one is East Java with score 6.906.

\section{CONCLUSION}

The top ten new development tourist destinations in Indonesia will be East Java, Banten, Jakarta, Central Java, North Sumatra, West Nusa Tenggara, Bangka Belitung, South Sulawesi, East Nusa Tenggara and North Maluku. 
According to the research, business environment performance has been successfully achieved by East Java, Jakarta and Central Java to other ten tourist destinations in Indonesia. However, the research found that several provinces are still in poor business environment performance. There are Banten, Bangka Belitung, Southeast Sulawesi, East Nusa Tenggara and North Maluku.

Most of the new development ten tourist destinations in Indonesia still need to developed their safety and security for tourist, even though they has already achieved in some of provinces, such as Banten, Central Java, West Nusa Tenggara, Bangka Belitung, Southeast Sulawesi and North Maluku. However, East Java, Jakarta, North Sumatra, East Nusa Tenggara is poor in safety and security.

Indonesia needs to improve health and hygiene performance for the new development their ten tourist destinations. Health and hygiene problem are found in West Nusa Tenggara, Bangka Belitung, Southeast Sulawesi, East Nusa Tenggara and North Maluku province. However, Jakarta is the most success province in improving their health and hygiene performance in their tourist places.

The competitiveness of human resource and labor market performance are dominance with poor result rather than ordinary result achievement. The poor achievement is in Central Java, Bangka Belitung, Southeast Sulawesi, East Nusa Tenggara, and North Maluku. However, Jakarta is the top competitive in its human resource and labor market performance.

Jakarta and Banten are successfully achieved especially in ICT readiness. However, North Sumatra, West Nusa Tenggara, Southeast Sulawesi, East Nusa Tenggara and North Maluku need to improve their ICT readiness.

East Java and Jakarta are the provinces that concern with their prioritization of travel and tourism performance. However, Indonesia still has some of provinces in their poor prioritization of travel and tourism performance, such as Banten, Bangka Belitung, Southeast Sulawesi, East Nusa Tenggara and North Maluku.

All the top ten tourist destinations in Indonesia are successfully competitive in terms of their international openness performance. This is the reason why the ten provinces have potentially increased their tourist destinations internationally.

Most of large economy provinces, such as East Java, Banten, Jakarta and North Sumatra are competitive enough in their price competitiveness performance. But, Southeast Sulawesi, East Nusa Tenggara and North Maluku are still in their poor performance.

Environmental sustainability is a matter of issue on new development ten tourist destinations in Indonesia. Most of provinces are still in poor achievement, such as East Java, Banten, Jakarta, Central Java, North Sumatra, West Nusa Tenggara and Bangka Belitung. There are only Southeast Sulawesi East Nusa Tenggara and North Maluku that improve their environmental sustainability performance.

The best air transport infrastructure performance for tourist destinations in Indonesia is in East Java, Banten and North Sumatra. Additionally, Jakarta and Central Java have fulfilled ordinary performance for air transport infrastructure. However, the rest of the provinces, such as West Nusa Tenggara, Southeast Sulawesi, Bangka Belitung, East Nusa Tenggara and North Maluku are still in poor performance for air transport infrastructure.

Ground and port infrastructure performance in Indonesia need to improve for tourist destinations. Most of the provinces, such as North Sumatra, West Nusa Tenggara, Bangka Belitung, Southeast Sulawesi, East Nusa Tenggara and North Maluku are in poor ground and port infrastructure performance.

Jakarta and Central Java have already competitive for the tourist service infrastructure. However, poor performance is still found in provinces that lack of tourist service infrastructure, such as West Nusa Tenggara, Bangka Belitung, Southeast Sulawesi, East Nusa Tenggara and North Maluku.

Most of the new development ten tourist destinations in Indonesia are in poor performance of natural resources, such as Banten, Jakarta, Central Java, West Nusa Tenggara, Bangka Belitung, Southeast Sulawesi, East Nusa Tenggara and North Maluku. However, East Java and North Sumatra still have natural resources for the tourist destination.

All the provinces must increase their cultural resources \& business travel to enhance successful performance, such as East Java, Banten, Jakarta, Central Java, North Sumatra, West Nusa Tenggara, Bangka Belitung, South Sulawesi, East Nusa Tenggara and North Maluku. 


\section{REFERENCES}

Base Transceiver Station (BTS) (Publication). (n.d.). (2015) Retrieved

Consulting, B. (n.d.). Nation Branding \& City Branding. Retrieved January 05, 2018, from https://www.bloom-consulting.com/en/nation-branding

Forest Area (Publication). (n.d.). (2017) Retrieved from

https://www.bps.go.id/publication/2016/11/30/613d3773b30c107a3c0d65cb/statistik-telekomunikasi indonesia.html

https://www.bps.go.id/publication/2017/07/26/b598fa587f5112432533a656/statistik-indonesia html

https://www.wttc.org/-/media/files/reports/economic-impact-research/2017-documents/globaleconomic-impact-and-issues-2017.pdf

Lindblad, J. T. (1998). Foreign investment in southeast asia in the twentieth century. London: Macmillan press.

Planet, L. (n.d.). Indonesia travel. Retrieved January 05, 2018, from https://www.lonelyplanet.com/indonesia

Post, T. J. (n.d.). Indonesia announces 10 new destination brands. Retrieved December 28, 2017, from http://www.thejakartapost.com/news/2017/06/15/indonesia-announces-10-new-destinationbrands.html

Telecommunication (Publication). (n.d.). Retrieved https://www.bps.go.id/publication/2016/11/30/613d3773b30c107a3c0d65cb/statistiktelekomunikasi-indonesia-2015.html

Telecommunication subscribers(Publication). (n.d.). Retrieved https://www.bps.go.id/publication/2016/11/30/613d3773b30c107a3c0d65cb/statistiktelekomunikasi-indonesia-2015.html

The Comparative Economic Impact of Travel \& Tourism (Rep.). (n.d.). Retrieved from https://www.wttc.org/-/media/files/reports/benchmark reports/the_comparative_economic_impact_of_travel_tourism.pdf

The Travel \& Tourism Competitiveness Report 2017 (Rep.). (n.d.). Retrieved from http://www3.weforum.org/docs/WEF_TTCR_2017_web_0401.pdf

Travel \& Tourism Competitiveness Index (TTCI). (n.d.). Retrieved December 28, 2017, from http://www.oceanhealthindex.org/methodology/components/tourism-competitiveness-index-tci

Travel \& tourism: global economic impact \& issues 2017 (Rep.). (n.d.). Retrieved from

Warsito. (2001). Taxlaw. Jakarta: PT. Rajawali Grafindo Persada. Page 128. 